\title{
Tradition in School Library
}

\author{
Tena-Vionea Pozaric, Mihaela Banek Zorica, Nevena Skrbic Alempijevic \\ University of Zagreb
}

\begin{abstract}
This research paper investigates the role of school library in managing and integrating tradition into the curriculum. The research was done through observation and semi-structured interviews with school librarians. One of the roles of the school library as an information and communication center is to nurture and promote heritage and tradition. There are different activities and projects initiated by the school librarians whose intention is to communicate tradition. The questions answered by this research are the ones of how school librarians define and perceive tradition.
\end{abstract}

\section{Keywords: Tradition, School Library, Curriculum, Invented Tradition, School Tradition \\ INTRODUCTION}

From the research review, most works are oriented towards learning and understanding different cultures for a more tolerant and respectful environment. Our research comes from another angle. We have moved one step backward and tried to understand how tradition can be used as an educational platform. First and foremost, for building information literacy capacity of students and secondary, teachers.

This research consists of two phases. The first phase was to investigate what is tradition and how it is implemented in school library programs so we can further investigate the integration of cultural heritage into the curriculum. This first phase of this research was done under the research for the purpose of the M.A. thesis and the second phase is still an ongoing process. The goal of the research was to investigate how school librarians are using tradition in their work, by using methods of development and presentation of tradition. Furthermore, how they perceive tradition and in what ways are they collaborating with other teachers were investigated.

\section{WHAT IS TRADITION?}

From the work of Glassie tradition is "a temporal concept, inherently tangled with the past, the future, with history" (Glassie 1995:399). He also admits that there are many variations of this term's definition and states that it is ,a continuous process situated in the nothingness of the present, linking the vanished with the unknown, tradition is stopped, parceled, and codified by thinkers who fix upon this aspect or that, in accord with their needs or preoccupations, and leave us with a scatter of apparently contradictory, yet cogent, definitions" (Glassie, 1995: 395). Still, he sees nothing wrong in having many definitions as it just brings to the wealth of semantical interpretation which enables us to better understand the complexity of the term.

In English language, tradition has its origin in French language and has been accepted during 14th century. The dictionary defines it as „The transmission of customs or beliefs from generation to generation, or the fact of being passed on in this way" (Oxford English Dictionary). According to the Merriam-Webster dictionary it is "a: an inherited, established, or customary pattern of thought, action, or behavior (such as a religious practice or a social custom), b: a belief or story or a body of beliefs or stories relating to the past that are commonly accepted as historical though not verifiable.

Folklorists, see tradition as a complex term, for instance, Seeger (according to Ben-Amos 1984:99) distinguishes "three separate meanings in the use of tradition: 1.An inherited accumulation of material; 2. the process of inheritance, cultivation, and transmission thereof; 3 . the technical means employed. On the other side Holbek (according to Ben-Amos 1984:99) sees it as the "process of handing down, the material that has been handed down, and the quality - positive or negative, depending on the speaker's perspectives - that people attribute to the subjects that connote either the process or material. 
What is a constant is that tradition is definitely related to history and our written or orally transferred memory. So tradition is often put in context with the terms like culture, customs, conventions, and routines. We understand that tradition and culture are interrelated and as Glassie states "Culture resist time, tradition is a temporal concept". (Glassie 1995:399). Further, he explains that they "share a vulnerability to superorganic conceptualization. Both are, at times, assigned deterministic roles in human affairs... are created by individuals out of experience" (Glassie 1995:398).

On the other hand, there is a difference between convention and routines. As Hobsbawm points out that they are not tradition since "... their functions, and therefore their justifications, are technical rather than ideological. They are designed to facilitate readily definable practical operations and are readily modified and abandoned to meet changing practical needs" (Hobsbawm 1983:5). What seems the most appropriate look about tradition is one that Noyes (2010:237) suggests tradition as communication which in her text is how scholarship focuses on tradition.

When discussing tradition there are also different types of tradition or different classifications. For instance Noyes (2010) divides it into three groups: tradition as communicative transaction; tradition as temporal ideology and tradition as communal property. Williams (2006) discusses tradition in the discourse of culture defining three levels: lived culture, recorded culture and selective tradition. On the other hand, Hobsbawm (1983) identifies specificity of tradition by exploring "invented tradition" which has its reference in the historic past but the continuity is largely factious. We have decided to take into account all these aspects of tradition and identify which ones are used by the school librarians.

\section{TYPES OF TRADITION APPLIED IN SCHOOL LIBRARY}

Tradition can be utilized in different ways. In Croatian school libraries tradition is mainly integrated into the curriculum through different activities such as projects, workshops, public discussions etc. It is usually presented through folk dance, exhibitions, readings, festivals or visits to information and heritage institution in the city, county or wider national territory. In some schools it is heavily promoted through school cooperative where even items created can be sold at the fairs and the income is again used for activities related to tradition. Pupils find history interesting and it engages them to further thinking and research about different topics. Also I enables them to connect same topic or historical period in different subjects.

School librarians' work in Croatia is divided into three segments - teaching, professional library work and cultural activities. Although tradition is integrated into educational segment it overlaps with the cultural and public activities. In this type of activities, there is an openness to organize cultural work through lectures, public discussions, competitions, fairs or to collaborate with other cultural institution (museums, archives, theaters). This category of activities is crucial in the context of expanding tradition.

So which types of tradition are used in the school environment? We could define 3 most commonly used:

- Tradition through performance - enables seeing and developing different customs and values. As Dressman states „Social identity is not a static "given" for individuals based on biology or history, nor can it be considered the summative product of all the social categories an individual can identify for herself or himself and so every performative act is no doubt a "doing" of multiple categories of identity involving complex patterns of interaction and exchange among them" (Dressman 1997:322-323).

For example, Croatian folklore customs in school presents a typical project where for instance all the performances are related to the certain dialect, for instance northwest Croatian dialect under the performance called „Kajkavijana“. During this performance period, different songs and dances are reproduced in traditional folk costume, plays performed on the dialect and literary works read. Through such performance, tradition is kept and history is not only retold but relived. Although, we focus on the ways pupils tradition is brought to pupils and how will they perform it this becomes a part of their everyday life performance.

- Selective tradition - based on Williams (2006) three levels of culture which he divides as following. The first level is the 'ideal' culture when it is a state or process of human perfection, in 
terms of certain absolute or universal values. The second level is the 'documentary' culture or when it becomes the result of intellectual and imaginative work in which human thought and experience are variously recorded. And the third one is the 'social' definition where culture is a description of a particular way of life, which expresses certain meanings and values not only in art and learning but also in institutions and ordinary behavior. This means that the culture can be either lived in a particular time and place and is accessible only to the ones that have lived in it or if it is recorded then it becomes available to everybody. Still, what we then experience is a selective tradition as there is only a part of the culture taken to represent the whole period.

Williams (2006) elaborates "the selection begins within the period itself; from the whole body of activities, certain things are selected for value and emphasis. In general, this selection will reflect the organization of the period as a whole, though this does not mean that the values and emphases will later be confirmed...The selective tradition thus creates, at one level, a general human culture, at another level, the historical record of a particular society; at a third level a rejection of considerable areas of what was once a living culture."

In the school library, selective tradition is when we choose parts of tradition which we want to use in order to accomplish our goals. Librarians can choose parts of tradition to bring it closer to the pupils and transfer to them only partial or selected customs and tradition. Selective tradition is very interesting because even if we choose a small part of some tradition or custom we do not change its original form but its context as it is usually adapted for the intended purpose

- Invented tradition - is taken to mean a set of practices, normally governed by overtly or tacitly accepted rules and of a ritual or symbolic nature, which seek to inculcate certain values and norms of behavior by repetition, which automatically implies continuity with the past. In fact, where possible, they normally attempt to establish continuity with a suitable historic past. (Hobsbawm, 1983:5)

School librarians choose which customs and tradition they will select to work with pupils. For example, wedding motive by whom they will show tradition. They are not taking all the customs from certain culture but selectively choosing wedding customs. In this way, they bring history to pupils. They choose elements from the history that they will bring to the present, present them and teach students about them. School librarians are actually inventing tradition because they choose something from history and then adapt it to their and their pupils' interests. The tradition that they are creating becomes a project. As this is lasting for several years it becomes a "school tradition".

\section{PERCEPTION OF TRADITION}

The research was conducted in three primary schools during a three weeks period in June 2015. It was done as a fieldwork where the researcher was not only interviewing school librarians but also observing them during their work with students. The observation did not influence the teaching process. They were asked to explain how they use tradition and to explain their behavior and actions. The rest of the school community was surveyed through the questionnaire to see their perception of tradition and how they define it.

Interviewed librarians have started from the task to transfer knowledge to students and have come to a conclusion that transferring knowledge to and building knowledge in pupils is best done by utilizing tradition. This proved to interest students the most. Librarians are using tradition, which is not fictive but is adapted for their own contexts, it is constructed and easily established but only in one environment i.e. school. Classes and schedules are fixed and time spends in the library enables correlation between curricula. This enables tradition to grow. One example of how they combine tradition with present activities is when teaching about reference work. They introduce reference work by explaining encyclopedia and putting it into the cultural context by explaining that the word in its today sense was first used by a Croatian philosopher Skalić, Pavao (lat. Paulus Scalichius) in 1559 in his work published in Basel - Encyclopaediae see orbis disciplinarum tam sacrarum quam profanorum epistemon.

So analysis of interviews showed that school librarians perceive tradition as: 
a) Tradition as heritage and foundation of social development - Tradition as a heritage can be material or intangible. Tradition is majorly seen as a heritage that was left by our ancestors who have thought that it is worth saving. Some of the explanation of tradition are: „Tradition is valuable heritage, both material and spiritual which we have received from our ancestors "; „It is cultural wealth of our ancestors"; „Tradition as a foundation for personal and social growth"; and „Behavioral habits (and things that go along with it) which are characteristic for certain group give a framework and thus are transferred from generation to generation".

b) Tradition as a custom - For them tradition is customs, oral communication, and intangible heritage. Most of the participant emphasize that tradition is mainly intangible heritage "Tradition, for me, is set of customs, values, habits, and ways of engagement and transfer of values which enrich life". This confirmed their viewpoint hat tradition is customs, habits, events, values, and items which delineate us and by which we define ourselves and our identity through history or by creating our own values. „Tradition is part of our everyday life. It is present in every pupil and school worker. Tradition and etiquette which I do with pupils together with practical handwork". For one of the participants, tradition is an even bigger concept as it represents her country and history, the best of both worlds. „Tradition is paintings...the best that people have made. It is our cultural heritage, our architecture, our literature, art"

c) Tradition through time and space - Tradition is definitely timely defined. As one of the participants states "It is something that exists from antiques“. Although sometimes we cannot prove how long certain tradition exists, it is a tradition if it is applied through several generations, and if it has entered social and cultural context as tradition. There are old traditions which are not rooted in folk and very little people know about them while on the other side there are relatively young traditions, existing only couple of years and the majority already knows about them. So the question is: Is this old tradition then less worth? All participants emphasized that tradition is keeping the things that were before us. Preservation and evaluation of our roots, culture, customs, and language through oral communication of the knowledge and customs which should be more actively promoted in culture and people. Because if we stop thinking about the past what does it say about our future? One participant summarizes ,it is set of customs that defines us today which should be kept, nurtured and never forget". Although majority have oriented themselves towards time dimension, some of them give more importance to the space dimension stating that „Cultural heritage of our region are clothes, music etc." They emphasize that this is their tradition which belongs to them as the inhabitants and the heiresses of the ones that have lived in a certain area not belonging to everyone.

d) Tradition and traditional customs - has been identified as two different concepts. One participant states that there is a huge difference between tradition and traditional customs, giving examples of traditional turkey for Christmas while traditional customs are the ones that live in the people such as the ones connected to the significant dates in the national calendar.

When asked about the importance of tradition and how they feel about the tradition in school. The majority of participants stated that tradition is valuable in a life of individual because it enriches people, family, and society in general. „Apart from being the most important thing from the past", ,it is a pledge of preserving identity and future". Another participant states that it teaches us the difference between right and wrong. While the other states that tradition ,enriches our everyday life, connect people and families and brings us closer to fundamental values".

Regarding tradition in school the majority thinks that tradition can be incorporated in any subject if the teacher is willing to do so. Still, tradition is currently best taught in a subject such as Croatian language and art. As tradition is incorporated in every aspect of our lives in schools it is best realized through different thematic activities.

\section{TRADITION AS PERFORMANCE IN SCHOOL LIBRARY}

Folklorist state that every creation of your own life is a performance so the question is are school librarians performing their „school librarians' role“. According to Kovačević et al. (2004:149) they 
„appear in a role of the person who will prepare a stage where learning will happen“. Therefore, the librarian is the person which brings pupils different kinds of knowledge. During their education, school librarians have learned what it means to be librarians and learn ways of how to be librarians so in a way they are acting their role in school and in front of pupils. As we all are entering different situations during our life, we are learning from examples, experience and upon it shape our behavior. We could say that even school librarians have their professional tradition which differs from teachers and other librarians.

In our interaction with others (pupils, teachers and parents) librarians present themselves in the best of light and they wish to bee is seen by others in this way, the way that they have presented themselves. This becomes more than just a role in the school library as this presentation becomes part of our daily life. As one of the participants states "even in my private life I am school librarian... when I enter bookshop and see a child choosing books, I instinctively approach the child and help him choose the best book for them...this happens even in a space that is not my original stage". According to Goffman this becomes a facade and not a mask as it is a general picture based upon facts gathered upon us. And when we become somebody, like school librarians, we accept prearranged facade thus this becomes our role. In words of Rihtman-Augušin, "culture is the way of thinking and behaving, action. Cultures are differing not only by how people work and live but what they think of themselves and how the act... what happens in the gap between their thinking and behaving" (Rihtman-Auguštin 1984:13). So the question is do we have our school library culture and how it differes in traditions and cultures around the world.

Each year by choosing a tradition such as wedding customs, they create a yearly event with singing and dancing and art products. In this way, school librarians take "old tradition" and create "new tradition" valuable to their school, pupils and the whole community. Projects of yearly performance involve teacher, pupils, and parents as they want to be part of this activity in the future. Furthermore, artifacts that pupils have made in "tradition workshops" are sold at fairs where students share their experience of handwork with the community.

\section{CONCLUSION}

Tradition in library becomes of growing importance as time passes by. With tradition, we transfer traditional customs to our pupils. Tradition is a great part of school librarians' work. Still, school librarians are not only becoming keepers of tradition but also inventors of the "new traditions".

Although their perception of tradition is overlapping, the activities and the ways how the communicate tradition differ. What makes integration of tradition into curriculum is the involvement of the school community.

\section{REFERENCES}

Bronner, S. J. (2000). The American concept of tradition: Folklore in the discourse of traditional values. Western Folklore, 59(2), 143-170.

Ben-Amos, D. (1984). The seven strands of tradition: Varieties in its meaning in American folklore studies. Journal of Folklore Research, 21(2/3), 97-131.

Dressman, Mark. (1997). Preference as performance: Doing social class and gender in three scholl libraries. Journal of Literacy Research, 29(3), 319-361.

Giddens, Anthony. (1994). Living in a post-traditional society. In U. Beck, A. Giddens, S. Lash (Eds.), Reflexive modernization: Politics, tradition and aesthetics in the modern social order (pp. 56109). Palo Alto, CA: Stanford University Press.

Glassie, H. (1995). Tradition. The Journal of American Folklore, 108(430), 395-412.

Greenwood, D. G. (2004). Culture by the pound: An anthropological perspective on tourism as cultural commodization. In S. B. Gmelch (Ed.), Tourists and tourism: A reader (pp. 157-169). Long Grove, IL: Waveland Press.

Hobsbawm, E. (1983). Introduction: Inventing traditions. In E. Hobswam, \& T. Ranger (Eds.), The invention of tradition (pp. 1-15). Cambridge, UK: Cambridge University Press. 
Hughes-Hassell, S., \& Stivers, J. (2015). Examining youth services librarians' perceptions of cultural knowledge as an integral part of their professional practice. School Libraries Worldwide, 21(1), 121-136.

Kovačević, D., Lasić-Lazić, J., \& Lovrinčević, J. (2004). Školska knjižnica - korak dalje. Zagreb, Croatia: Zavod za informacijske studije : altaGama.

Noyes, D. (2010).Tradition: Three traditions. Journal of Folklore Research, 46(3), 233-268

Požarić, Tena-Vionea. (2016). Predstavljanje tradicije u školskim knjižnicama u Zagrebu. Master's thesis. Zagreb, Croatia: Filozofski fakultet.

Rihtman-Auguštin, D. (1984). Struktura tradicijskog mišljenja. Zagreb, Croatia: Školska knjiga.

Williams, R. (2006). The analysis of culture. In J. Storey (Ed.), Cultural theory and popular culture: A reader (pp. 32-40). Athens, GA: University of Georgia Press. 